\title{
Shopping to belong: Testing and advancement of a framework on consumer behaviour aimed to promote belonging
}

\author{
Vargas-Bianchi, L. \\ Instituto de Investigación Científica, Universidad de Lima \\ Ivargas@ulima.edu.pe \\ Orcid: 0000-0002-9027-7673
}

Citation:

Vargas-Bianchi, L. (2020). Shopping to belong: Testing and advancement of a framework on consumer behaviour aimed to promote belonging. SocArxiv preprint. DOI: 10.31235/osf.io/uqvfa

\begin{abstract}
Much research has been conducted on how consumption is related to human relations, for example, consumer communities organized around specific brands or the way people use products to define their own identity and transmit a desired image. However, only a scarcity of research has examined the consumption process when the fundamental intention is to leverage group belonging. The literature comprises a single theoretical framework that describes this behaviour, a nascent proposition that has not been tested. This study reviews the transferability of the model and its descriptive extent of the phenomenon in a different context than the one originally used for its proposal. A qualitative deductive case study and a pattern matching analysis technique were employed. The findings revealed that the model is transferable, thus revealing its suitability for future research on consumer behaviour intentionally aimed to promote belonging. The study also expands the framework with precisions on its conceptualization.
\end{abstract}

\section{Keywords}

Consumer behaviour, belonging, need to belong, consumption, consumption activities

\section{Introduction}

As social beings we live immersed in relationships with one another that define our identity and behaviour within the cultural framework in which we live. Consumption is part of that social reality, which is noted in peers' influence on purchasing decisions as well as the assessment of products and brands based on the opinions of acquaintances (Schulz, 2015). Researchers argue that consumption is related to the desire to belong, since purchasing behaviours do not occur in isolation from social ties and affiliation with family, community, or other groups (Arvidsson \& Caliandro, 2016; Bettman \& Escalas, 2005; Cova \& Pace, 2006; McAlexander et al., 1981; Muniz \& O'Guinn, 2001). Studies show that consumers relate to each other using of specific brands and enjoy satisfaction through shared emotions (Ruane \& Wallace, 2015). For example, brand communities have revealed how individuals relate in situations where a brand is the foundation of their encounter (Muniz \& O'Guinn, 2001; Arvidsson \& Caliandro, 2016; Goulding, Shankar, \& Canniford, 2013; Grzeskowiak \& Sirgy, 2007). Some authors have researched extensively how individuals use products to reflect their own identity. Belk's 
work on the extended self through symbolic incorporation of object meanings is one of the most influential studies (Belk, 1988, 2017). He argues that the person relates to some brands as if they were a reflection of himself, as a means for self-representation and a collective conception of self. While this connects to the fact that people present and share their identity with others, it does not consider the steps that people follow when they intentionally select and use possessions to support their affiliation to a group. The literature on this topic coincides that the search for satisfying belongingness gives rise to a series of behaviours that are influenced by other people who are members of a group to which they belong, or wish to belong, These conducts can, in opportunities, influence purchasing choices. Despite related studies, not much research has modelled behaviour by describing the stages entailed when people use products or brands to consciously leverage group belonging. No accepted model is found in academic literature that describes this consumption action and allows future analysis (Arias \& Otnes, 2016, 2017; Mead et al., 2011). Arias \& Otnes $(2016,2017)$ proposed an initial theoretical framework entitled Belonging Process (BP) that explains the process that individuals follow when they consume to meet their need of belonging. The BP theoretical framework and its transferability to explain the phenomenon in contexts other than their original work has as yet not been analysed. The purpose of the present study was to test the theoretical framework and establish whether it is dependent on cultural and social context in which it was originally performed. The study seeks to advance the development of this nascent model, so it provides a basis for further comprehension and analyses on belonging related consumption. Consequently, the study encompassed two research questions:

RQ1: Does the BP theoretical framework describe and explain consumption behaviours that aim to leverage individuals' group belonging in a cultural and time context that is different from the original study?

RQ2: Are there new or distinct elements that complement the descriptive capability of the constructs that make up the BP theoretical framework and the relationships between these constructs?

Research has demonstrated the reliability of the BP theoretical framework so as to benefit future research on how individuals deliberately take advantage of consumer activities to benefit their group belonging. This revision of the BP model contributes to the understanding of consumption practices and purchasing decisions, which are not based on the functional characteristics of a product or the value proposals expressed by each brand, but rather on the social value that the individual gives to goods available in the market. The findings of this study contribute to the growing body of knowledge about person-object-person relationships (Belk, 1988; McCracken, 1986) and belonging-related consumer behaviour.

\section{Literature review}

Since the development of Maslow's motivational scheme and the contributions of Bowlby's attachment theory, belonging has been present in human behaviour studies as a condition to ensure well-being (Grzeskowiak \& Sirgy, 2007) and as an influence on interpersonal relations (Nichols \& Webster, 2013). Belonging studies describe the concept as the human need to experience membership and acceptance in a group and by its members; it may be regarded as a reciprocal dynamic because group fellows 
expect the individual to reciprocate the attention (Mellor, Stokes, Firth, Hayashi, \& Cummins, 2008; Pickett, Gardner, \& Knowles, 2004). Scholars have argued that the desire to belong influences the purchase decision of a variety of product categories including clothing, travel destinations and consumer electronics. Furthermore, these products assist people in taking care of their social relationships (Vladas Griskevicius, \& Kenrick, 2013).

In their extensive literature review, Baumeister and Leary (1995) proposed a hypothesis about the need to belong (NTB) that has been a central influence in studies related to this subject. They noted that belonging is a fundamental human need, which explains much of social behaviour. They further stated that people have a strong innate inclination to form and maintain a minimum amount of stable and meaningful interpersonal relationships. They added that when NTB is not met, individuals experience a variety of negative emotional and cognitive effects. Furthermore, Baumeister and Leary noted that two conditions are required for this desire to be met: interactions with other people must be frequent and affectionately pleasant, and these interactions must occur in a lasting context and be of emotional concern and attention to others as the individuals must experience or believe that their peers are concerned with their well-being. Related research agrees that NTB is associated with people's sensitivity to the perception of signals that proof acceptance (or rejection) by members of a group. Some authors relate the desire of people seeking for group affiliation to the fact that they are attentive to any information that reveals something about their peers (Leary, Kelly, Cottrell, \& Schreindorfer, 2013; Pickett et al., 2004). Sheth, Newman, \& Gross (1991) state that the individuals' purchase decision process includes a social variable. They call it social value, meaning the perceived utility of the product's association with specific groups. Brands or products can serve as guides for signalling approval, and thus can perform as instruments to assist relationships with others, and to enable affiliation (Berger \& Heath, 2007; Hammerl et al., 2016; Ratner, Kahn, \& Kahneman, 1999). Baumeister and Leary also described different dimensions with which this need may be related. Although they did not mention that purchase actions are related to belonging, they linked NTB to diverse behaviours that derive from this motivation. For example, recent studies have argued that the desire to belong manifests in people's behaviours on social media such as Facebook and Instagram when they share photographs and/or messages aimed at favouring their connection with groups of their interest (Nadkarni \& Hofmann, 2012; Seidman, 2013).

Similarly, in group conformity, individuals purchase products to adhere to group norms and attempt to maintain homogeneity with the tastes of group members by their purchases (Beran, Kaba, Caird, \& McLaughlin, 2014; Cialdini \& Goldstein, 2004; Grotts \& Johnson, 2013). Several studies on reference group influences have suggested a relation between group affiliation and the use of specific brands by its members (Bearden \& Etzel, 1982; Bearden et al., 1989; Bettman \& Escalas, 2005; Burnkrant \& Cousineau, 1975; Childers \& Rao, 1992). Authors establish a link between belongingness need and purchase actions in group conformity (Beran, Kaba, Caird, \& McLaughlin, 2014; Cialdini \& Goldstein, 2004; Grotts \& Johnson, 2013; Algesheimer, Dholakia, \& Herrmann, 2005). This phenomenon is observed when individuals acquire products to adhere to group norms, or when their purchasing action is likely to be consistent with the tastes or opinions of group members, for example in the choice of a particular product model or brand (V. Griskevicius, Goldstein, Mortensen, Cialdini, \& Kenrick, 2006; J. K. Park \& 
Feinberg, 2010). White and Argo (2009) argue that consumers avoid products that signal their membership of groups to which they associate a negative perception. Various works that have analyzed the influence of reference groups point out the relationship between the affiliation to a group and the use of trademarks by its members (Bearden \& Etzel, 1982; Bearden et al., 1989; Bettman \& Escalas, 2005; Burnkrant \& Cousineau, 1975; Childers \& Rao, 1992). This phenomenon is also noted, for example, when a person claims that he or she would buy a specific brand because friends or colleagues approve of it, or because he or she behaves according to the habits or rules followed by other members of the community (Algesheimer, Dholakia, \& Herrmann, 2005). Veloutsou and Moutinho (2009) have stated that, because of the influence of the group, sometimes brand loyalty can be confused with group loyalty, when the individual's behavior is primarily identified with that of the group.

Research has also described the effect between individuals within the so-called reference groups. A reference group is a collective, real or imaginary, that exerts a significant relevance in the evaluations, aspirations or conduct of the subject (Bettman \& Escalas, 2005; Grzeskowiak \& Sirgy, 2007; C. W. Park \& Lessig, 1977). Within the framework of the reference group, consumers likewise find a source of information on ratings or attitudes from other people who share similar beliefs (Bettman \& Escalas, 2005). The influence that the reference group exerts on individuals can include perceptions about a specific brand (Ruane \& Wallace, 2015; Veloutsou \& Moutinho, 2009), for example, when a product represents the beliefs or attitudes of the group members. It can happen that the consumer does not even like the product, and yet may wish to purchase it in order to gain acceptance from members of his or her reference group (Belk, 2017; Grotts \& Johnson, 2013).

Belk $(1988,2017)$ argues that individuals incorporate symbolic meaning to possessions, so that certain objects or places become part of his personality. The objects allow their owner to elaborate a concept of "who I am", making them a means for personalization and self-representation. The researcher explains that these relationships are not composed of only two elements (person-thing), but that three intervene: person-thingperson. This relationship extends to the meaning that people give to products as long as it allows them to link up with other subjects and find benefits in this relationship. Ahuvia (2015) points out that the formula 'person-thing-people' is a concise description of the phenomenon that links individuals and products and calls it "the first axiom of Belk". The author relates the extended self with group affiliation by arguing that one way to express it is through shared symbols of consumption. These symbols define what he calls the group self. Products such as clothing, cars, jewelry, or attendance to clubs or entertainment events express an individual sense of self, and also point out group identity. Belk also mentions collectively owned products as ways of demonstrating group affiliation, although he does not elaborate on the process people follow when seeking group belongingness.

The suggestion that consumption is often a person-thing-person relationship, or clientbrand as proposed by Muniz \& O'Guinn (2001), is witnessed in the so-called brand communities, where a specific brand functions as the axis that gives rise to interpersonal closeness and grounds the sense of belonging between individuals in that community (Algesheimer et al., 2005; McAlexander, Schouten, \& Koenig, 2002; Muniz \& O'Guinn, 2001). Brand communities are a set of social relationships that are structured 
around the use of a particular brand (Ahuvia, 2005; Berger \& Heath, 2007; Bettman \& Escalas, 2005; Goulding et al, 2013; Muniz \& O'Guinn, 2001), between members who share a system of values, standards and representations (Cătălin \& Andreea, 2014), and who have an identity based on that brand (McAlexander et al., 1981), or around shared ownership of a product (Ahuvia, 2005; Ruiz, 2005). Some authors refer to brand tribes rather than communities, although there does not seem to be any consensus on the differences between the two terms, and they are used interchangeably (Cova \& Pace, 2006).

\section{Belonging Process theoretical framework}

Consumption and group affiliation have been a central question in the study of consumer culture and social processes. Research on brand communities, and on the use of possessions to constitute a person's identity, shed light on this phenomenon. However, they do not descend to describing the process that consumers follow when marketed goods are consciously used to promote belongingness. A small number of studies have identified this gap and analysed the proactive search for belonging according to which people instrumentalize consumption (Mead et al., 2011). Arias and Otnes $(2016,2017)$ conducted exploratory work to clarify how people take advantage of consumption to achieve favourable results related to their sense of belonging and proposed a theoretical framework to analyse this phenomenon. Their qualitative analysis based on narratives from university students, formed the basis of the Belonging Process (BP) theoretical framework.

In their work, Arias \& Otnes $(2006,2017)$ give special relevance to arguing that belonging is not a fixed state of practice, as postulated by studies on NTB (Baumeister \& Leary, 1995), but that it is a procedural and fluid phenomenon. So much so they call their theoretical scheme the Belonging Process (BP). The authors affirm that this process is composed by several constructs, which occur sequentially. Their writings seem to have a double purpose: to argue that belonging is a fluid reality, and to analyse consumer behaviour when their intention is to gain a sense of belonging. The present study does not intend to examine whether the sense of belonging is in all cases fixed or procedural. A description of the six constructs the BP comprises follows.

Cultural context: Arias and Otnes $(2016,2017)$ noted that it includes the broadest drives that shape the BP framework. It includes both sociological and cultural forces such as social norms or built expectations among the members of that context. Its role in the belonging process is to encompass its influences on each construct and the way they are related entirely.

Belonging targets: Arias and Otnes $(2016,2017)$ argued that belonging targets comprise the social entities to which the individual seeks to belong, to be a member of. They may exist on three levels: micro, meso and macro. These targets place belonging within individuals' context in which their behaviour occurs. Belonging targets influence the identification of the belonging conduits and provide belonging cues, so consumers are able to gauge their status concerning group belonging. The effect can be direct, such as consumption suggestions received or heard from peers of the target group or indirect, for example, when the subject notices the consumption patterns of the target group members. 
Belonging conduits: These are the resources available on the market that consumers employ to leverage their belonging status of a group, that is, the belonging target. They include products, services, and brands. Furthermore, their use depends on their symbolic or functional properties. Arias and Otnes $(2016,2017)$ explained that the way a product or experience is consumed may also serve as a conduit. As noted previously, $\mathrm{BP}$ proponents have proposed that belonging targets influence the selection that people make regarding conduits. Once the group to which individuals wish to belong is identified, they distinguish the consumption means that lead them to that goal. Identifying consumer products and/or behaviours may be directly influenced by group members.

Belonging cues: These include the cues or signals that consumers receive from the target group members that assist them to acknowledge their progress toward their belonging goal. Cues are internal when they originate from the person's own subjective perception and external when they originate from a third party. An example of the former is when consumers buy products that they consider to be exclusive or consumed by the elite. An example of the latter occurs when individuals receive compliments from group members because of something they are wearing or planning to buy.

Belonging barriers: Arias and Otnes $(2016,2017)$ defined these as forces that prevent people from achieving their expectations of belonging to the target group. They argued that experiences of social exclusion do not only originate from interpersonal relationships, but are also due to personal and psychological factors that can hinder or even limit individuals' progress toward their goal of belonging.

Belonging results: These are also known as outcomes and include those experiences of feelings of belonging that individuals achieve in relation to the belonging target. Outcomes may range from simple interactions with people that belong to the group to the establishment of stable relationships.

Arias and Otnes $(2016,2017)$ stated that their proposed framework is a preliminary theorization about consumption and its relationship with the desired sense of belonging. BP comprises the elements that are present in people's behaviour when proactively consuming goods with the primary aim of leveraging their belonging status. According to Arias and Otnes, this framework and its constructs afford academics a vocabulary with precise theoretical content that allows further research on belongingrelated consumption.

\section{Methods}

A qualitative deductive method, which seeks to analyse a theory through testing and the review of its results, was employed so as to confirm or reject the BP theoretical framework (Creswell, 2007; Hyde, 2000; Løkke \& Sørensen, 2014; Miller \& Crabtree, 2005; Bitektine, 2008). Consequently, whether the theory is transferable to a context different from the original is ascertained (Yin, 2018). This methodological procedure requires the researcher to work on an existing theory, collect data to prove it, and subsequently, reflect on its confirmation (or rejection) grounded by the findings (Creswell, 2014). Furthermore, this study was exploratory. The latter approach is 
suitable for obtaining information from a theoretical field that is preliminary or in which there is partial knowledge (Bitektine, 2008; Creswell, 2007; Sinkovics, 2017).

\section{Study design}

A single case study design was adopted (Yin, 2018). The case study allows a phenomenon, referred to as a case, to be studied in depth and within its context, embracing the fact that the boundary between the phenomenon and the context is not clearly drawn (Creswell, 2007; Yin, 1981, 2006, 2018). In this study, the case was defined as the consumption behaviour consciously directed to leverage group belonging. The participants included 12 young females and males who were intentionally selected as they had consciously performed consumption actions to favour their belonging status. Arias and Otnes (2017) used a similar population in their original work in terms of age and dedication to their higher education responsibilities. Likewise, various studies have suggested that young people show greater sensitivity to group belonging and agreement with their peers (Hornsey \& Jetten, 2004; Oishi, Diener, Suh, \& Lucas, 1999).

The case limits included the following: participants had to be aware of having made purchases and consumptions with the primary purpose of favouring their group belonging status during the previous year and they had to choose to purchase or use specific products or brands in order to assist their group belonging status. The time limit of the case was three months. The inclusion criteria for participant selection were: enrolment in a higher education institution; between the ages of 19 and 23 years; and classification as a medium, medium-high, or high socioeconomic level. An equal number of males and females were chosen, and their mean age was 22 years (median $=22$; mode $=23 ; \mathrm{SD}=1.20$ ).

All the participants had a Western background, belonged to a Latin America social and cultural frame of reference and were immersed in a metropolitan urban life in an emerging economy.

\section{Analysis technique}

A pattern matching technique (Trochim, 1985; Yin, 2018; Almutairi, Gardner, \& McCarthy, 2014) following the procedure proposed by Pearse (2019) was employed in the analysis. In the pattern matching design, propositions articulated in the tested theory are linked with data obtained in the study by comparing a pattern of observed results with another pattern of the expected theory-derived values (Campbell, 1975; Hyde, 2000; Sinkovics, 2017; Bitektine, 2008). Hak and Dun (2010) referred to both extremes of information as the observed pattern and expected pattern because theories predict anticipated patterns, which are considered to be hypotheses. Yin (2018) asserted that when the patterns revealed empirically coincide with the expected ones, the result helps to confirm these hypotheses and thus, the theory's validity is strengthened. Furthermore, a descriptive coding analysis was conducted on the collected information to have an in-depth understanding of the phenomenon under study within the limits of the tested theory (Saldana, 2013). Verbalization of consumption experiences directed to aid group belonging was established as the context unit to conduct the coding. NVivo 12 was employed for both the pattern matching and coding analysis. 


\section{Propositions}

To form the expected pattern, seven BP theory-based propositions were formulated:

P1a-Belonging targets: The individuals whose consumption behaviours are intended primarily to leverage belonging declare that they identify and establish the groups to which they belong.

P1b - Belonging targets: The individuals identify and set the groups to which they seek to belong.

P1c - Belonging obstacles: The individuals identify factors that obstruct them from belonging to a current or future group.

P2a - Belonging conduits: The individuals identify products, services and brands or behaviours whose consumption will maintain their group belonging and projected membership to a belonging target.

P2b - Belonging conduits establishment: The individuals confirm that the belonging target directly or indirectly influences the establishment of belonging conduits.

P2c - Belonging cues type: The individuals confirm that the products, services and brands whose use leverage group belonging do so because of their functional or symbolic type.

P3 - Belonging cues: The individuals establish and identify the cues that show their belonging status relative to the belonging target.

\section{Codebook}

In accordance with these propositions, the researcher developed a codebook to display the empirical data from the tested theory to allow the pattern matching analysis (Fereday \& Muir-Cochrane, 2006; Pearse, 2019; Stuckey, 2015; Yukhymenko et al., 2014). The codebook is displayed in Table 1 :

Table 1. Code book based on the BP theoretical framework of Arias \& Otnes.

\begin{tabular}{ll}
\hline $\begin{array}{l}\text { P1a } \\
\text { Group } \\
\text { identification }\end{array}$ & Codes \\
\hline & KNOWSGROUP - knows the groups it already belongs to \\
$\begin{array}{l}\text { P1b } \\
\text { Belonging Target }\end{array}$ & $\begin{array}{l}\text { MACRO - evidence that the target set is macro } \\
\text { MESO - evidence that the target set is meso }\end{array}$ \\
\hline $\begin{array}{l}\text { P1C } \\
\text { Obstacles of } \\
\text { belonging }\end{array}$ & IDOBO - evidence that the target set is micro \\
\hline $\begin{array}{l}\text { P2a } \\
\text { Conduit }\end{array}$ & $\begin{array}{l}\text { IDPRODCOND - identifies a product that serves as a belonging conduit } \\
\text { IDCONDCOND - identifies a behaviour that serves as a belonging }\end{array}$ \\
\hline
\end{tabular}




\begin{tabular}{ll}
\hline $\begin{array}{l}\text { P2b } \\
\begin{array}{l}\text { Selection of } \\
\text { belonging ducts }\end{array}\end{array}$ & $\begin{array}{l}\text { TARGETINF - manifests (implicitly or explicitly) that target group } \\
\text { influences the establishment of conduits }\end{array}$ \\
\hline $\begin{array}{l}\text { P2c } \\
\begin{array}{l}\text { Character of the } \\
\text { conduits of } \\
\text { belonging }\end{array}\end{array}$ & $\begin{array}{l}\text { FUNCT evidence that the belonging conduit is functional } \\
\text { SYMB -evidence that the belonging conduit is symbolic }\end{array}$ \\
\hline $\begin{array}{l}\text { P3 } \\
\begin{array}{l}\text { Signs of } \\
\text { belonging }\end{array}\end{array}$ \\
\hline
\end{tabular}

\section{Data collection}

In-depth semi-structured interviews were conducted. At the researcher's request, teachers from three private higher education centres provided a list of students. They were requested via email to participate in the study. Those who responded in the affirmative received a digital questionnaire so as to evaluate whether they met the case limits and inclusion criteria. Those who complied were selected to be part of the case group. Interviews were conducted telephonically. An inquiry guide (Table 2) based on the study propositions was used to guide the interviews, which lasted an average of 25 minutes. A professional service was used to transcribe the recorded interviews.

Table 2. In-depth enquiry guide and correspondence with the study propositions.

\begin{tabular}{lll}
\hline Topics & Questions & $\begin{array}{l}\text { Corresponding } \\
\text { propositions }\end{array}$ \\
\hline $\begin{array}{l}\text { Target groups } \\
\text { belonging }\end{array}$ & Have you identified the groups you belong to? & (P1a) \\
\cline { 2 - 3 } & Have you identified the groups you want to belong to? & (P1b) \\
\hline & $\begin{array}{l}\text { Can you identify which products/services support your } \\
\text { group belonging status? }\end{array}$ & (P2a) \\
\cline { 2 - 3 } $\begin{array}{l}\text { Can you identify which buy/use behaviours support } \\
\text { products/services/ } \\
\text { brands for belonging }\end{array}$ & $\begin{array}{l}\text { Wour group belonging status? } \\
\text { identification of those products/services/brands? }\end{array}$ & (P2b) \\
\cline { 2 - 3 } & $\begin{array}{l}\text { Does anything or anybody define products that } \\
\text { promote belonging status (to the target group)? }\end{array}$ & (P2b) \\
\cline { 2 - 3 } & $\begin{array}{l}\text { Have you experienced or recognized obstacles in the } \\
\text { quest for group belonging? }\end{array}$ & (P1c) \\
\hline \multirow{2}{*}{$\begin{array}{l}\text { Signs of belonging } \\
\text { status }\end{array}$} & $\begin{array}{l}\text { How do you notice when a product/service/brand is } \\
\text { favouring your group belonging? }\end{array}$ & (P3) \\
\cline { 2 - 3 } & $\begin{array}{l}\text { Do you need someone to confirm the } \\
\text { product/service/brand used is aiding group belonging? } \\
\text { What happens if you don't get confirmation? }\end{array}$ & (P3) \\
\hline
\end{tabular}

Three months after the interviews, all the participants were contacted by email and asked to complete a follow-up on-line questionnaire. The same topics in the interview guide (Table 2) were in the questionnaire. Participants answered each question on a five-point Likert scale, ranging from 1 (strongly disagree) to 5 (strongly agree). They also completed open-ended questions. The purpose of the follow-up questionnaire was a further source of information to assess the consistency of data obtained from the interviews. Six of the participants completed the questionnaire. 
In relation to the ethical aspects of the study, the participants' anonymity and confidentiality was preserved by assigning a letter code to each informant. Furthermore, participation was voluntary and they all signed an informed consent form before their interviews.

\section{Results}

Matches were revealed between all the theoretical and empirical patterns thus indicating that the BP theoretical framework can be transferred to a different context. The matching patterns are depicted in Table 3:

Table 3. Coincidence between predicted patterns and empirical patterns.

\begin{tabular}{|c|c|c|c|}
\hline Construct & Proposition & Theoretical pattern & Empirical pattern \\
\hline \multirow{3}{*}{$\begin{array}{l}\text { Belonging } \\
\text { Targets }\end{array}$} & P1a & $\begin{array}{l}\text { The person manifests that } \\
\text { he/she identifies and } \\
\text { establishes the groups to } \\
\text { which she/he belongs. }\end{array}$ & $\begin{array}{l}\text { The person identifies and establishes the groups to } \\
\text { which she/he belongs. It can be seen that this is a } \\
\text { non-systematized identification of groups, but } \\
\text { groups with roughly defined identities. }\end{array}$ \\
\hline & $\mathrm{P} 1 \mathrm{~b}$ & $\begin{array}{l}\text { The person states that she/he } \\
\text { identifies and sets the groups } \\
\text { to which she/he seeks to } \\
\text { belong. }\end{array}$ & $\begin{array}{l}\text { The person states that she/he identifies and sets the } \\
\text { groups to which she/he seeks to belong. Groups may } \\
\text { be micro, meso, macro indistinctly and regardless of } \\
\text { whether the participants recognized them that way. }\end{array}$ \\
\hline & P1c & $\begin{array}{l}\text { The person identifies factors } \\
\text { that may be an obstacle to } \\
\text { belonging to a target group. }\end{array}$ & $\begin{array}{l}\text { The person identifies factors that may } \\
\text { straightforwardly hinder obstacles to a target group. }\end{array}$ \\
\hline \multirow{3}{*}{$\begin{array}{l}\text { Belonging } \\
\text { Conduits }\end{array}$} & P2a & $\begin{array}{l}\text { The person identifies } \\
\text { products/services/brands } \\
\text { whose purchase or use he/she } \\
\text { considers promotes the } \\
\text { desired group belonging } \\
\text { status. }\end{array}$ & $\begin{array}{l}\text { The person identifies products/services/brands } \\
\text { whose purchase or use he/she considers promotes } \\
\text { the desired group belonging status. He/she also } \\
\text { identify means available in the market that enhance } \\
\text { the information and exhibition of the conduits. }\end{array}$ \\
\hline & $\mathrm{P} 2 \mathrm{~b}$ & $\begin{array}{l}\text { The person states that the } \\
\text { belonging target directly or } \\
\text { indirectly influences the } \\
\text { establishment of the belonging } \\
\text { conduits. }\end{array}$ & $\begin{array}{l}\text { The person states that the belonging target directly } \\
\text { or indirectly influences the establishment of the } \\
\text { belonging conduits. The person states that the } \\
\text { belonging target directly or indirectly influences the } \\
\text { establishment of the belonging conduits. However, } \\
\text { the belonging target does not appear as } \\
\text { determining, since a level of flexibility or } \\
\text { interpretation is perceived by the subject about } \\
\text { available goods useful to relate to a group. }\end{array}$ \\
\hline & $\mathrm{P} 2 \mathrm{c}$ & $\begin{array}{l}\text { The person shows that the } \\
\text { products/services whose use } \\
\text { favours belonging status do so } \\
\text { because of a functional or } \\
\text { symbolic nature. }\end{array}$ & $\begin{array}{l}\text { The person shows that the products/services whose } \\
\text { use favours belonging status do so because of a } \\
\text { functional or symbolic nature. This nature does not } \\
\text { seem to be an element to which they are aware of } \\
\text { when choosing a good as a conduit. }\end{array}$ \\
\hline $\begin{array}{l}\text { Belonging } \\
\text { Cues }\end{array}$ & P3 & $\begin{array}{l}\text { The person establishes and } \\
\text { identifies the cues that } \\
\text { confirm his/her belonging } \\
\text { status relative to the belonging } \\
\text { target. }\end{array}$ & $\begin{array}{l}\text { The person establishes and identifies the cues that } \\
\text { confirm his/her belonging status relative to the } \\
\text { belonging target. However, the guidelines do not } \\
\text { appear to be conditional, as the person can self- } \\
\text { confirm membership when they consider that a } \\
\text { product or consumer practice points their } \\
\text { membership in the group. }\end{array}$ \\
\hline
\end{tabular}

Belonging targets: The analysis revealed that the participants identified and also established the groups to which they wished to belong (P1a). A participant thus expressed this: "I feel a need to belong, for example, to work for one of the companies in the financial sector (...) for a large company. I particularly feel that need to want to belong to that group, leave office hours and talk with people" (Participant N, male). Another 
noted, "Putting myself on the side of being fit, so now I am working a lot in the gym, exercising, changing to that lifestyle" (Participant $\mathrm{M}$, male). These targets had the properties of being macro, meso or micro groups, indistinctly and regardless of whether the participants recognize them that way.

Belonging obstacles: The interviewees displayed awareness that there are factors that can hinder membership to a target group (P1c). They shared experiences in which they identified problems in their efforts to belong. Participant R (male) argued, "Before (...) he carried less [weight] (...), however, he had all the motivation, he ate the same healthy, he trained, but he carried less than that because he was just starting, and he was not part of the group even though he trained just like them, despite [doing] the same things". One participant shared that if her close group of friends were consuming a product from a well-known coffee shop and she was not, she felt "like we were all not going at the same pace" (Participant A, female). It was perceived that the nature of the obstacles is broader than mere social exclusion as stated by Arias and Otnes $(2016,2017)$ who explained that obstacles that are associated with belonging can be of a different nature and origin. The participants noted this when they said that an incorrect choice of conduits can prevent or damage their belonging effort. Participant J (male) shared a situation where those who tried to approach the group carried out consumer actions whose members perceived as factitious: “... was entering the group and tried to buy whiskey, we really don't care; he wanted to get into the group with that and that was spotted". In relation to the diverse levels of group conformation, it is possible that most of the belonging experiences of those shared refer to groups of the micro and meso levels. However, no participant mentioned belonging to a macro group.

Belonging conduits: It was revealed that the participants found products and services that, when consumed, they considered favouring group belonging (P2a). One participant argued that people in a group "usually use a lot (...) these black coats, I don't know exactly the brand (...) the people that most often uses them are the university students" (Participant K, male). Another participant referred to products and belonging as follows: "Many times my friends also comment on a certain product, I also want to be part of the group to know how good [the product] is" (Participant I, female). Arias and Otnes $(2016,2017)$ explained that the market offers a variety of possibilities for constituting conduits such as the use or constant mention of brand names, the use of similar products by group members and the display of logos and/or brand identifying signs. The participants also gave examples when they completed the questionnaire: "Depending on which brands the majority [of people] use to achieve similarity. In the case of groups of [same] hobbies or [same] professions, it always favours having products of key brands that contribute to the work [they make]" (Participant Y, female). A participant also referred to a new feature, namely, the geo-location of the purchased product as information that can be used as a belonging conduit. He acknowledged sharing a consumer product used as a conduit when posting it on his Instagram account that included the purchase location in the story. Another participant shared, "Even now you can put a location on it, so it's like, you not only show the cup [of Starbucks coffee] but where we are, where the brand is from" (Participant E, female).

In relation to mentioning branded products among the participants' experiences, their predominance as belonging conduits was noticeably expressed. Using products such as tennis shoes with specific characteristics and the consumption of vitamin supplements 
among those who formed groups around a sport appeared to use particular brands predominantly as vehicles to favour belonging. As depicted in the hierarchy chart that compares this proposition to other codes (Figure 1), the prominence of its position is similar to $\mathrm{P} 2 \mathrm{a}$, which identifies products or services as belonging conduits.

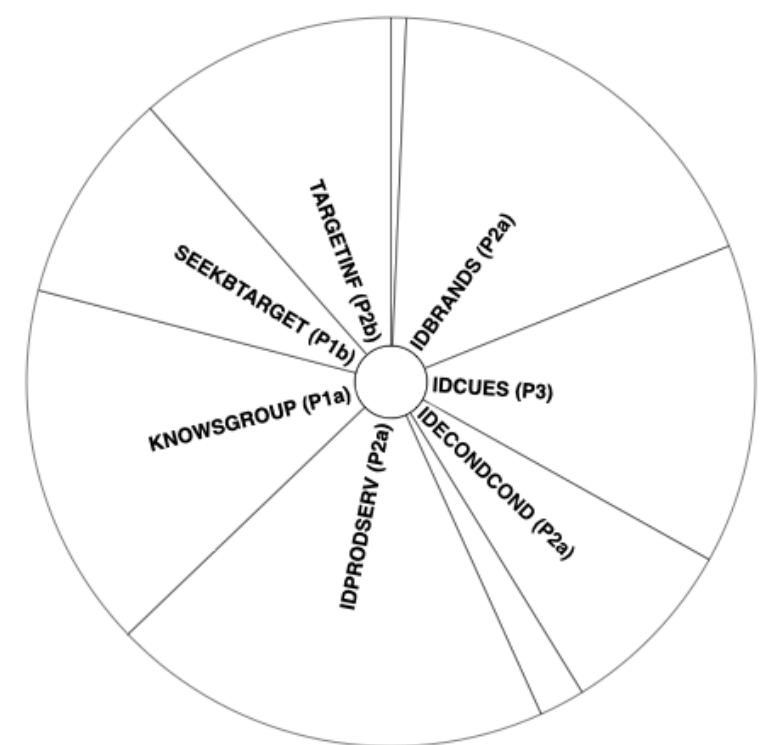

Figure 1. Radial hierarchy chart illustrating the prominence of codebook positions and the prominence of the code identification of brands (IDBRANDS) relative to other propositions among the participants.

The participants experienced consumer goods as products or as branded products as equally useful provided they were means available in the market that could serve as a vehicle to meet their need to belong to the group of choice. One participant shared, "I feel that if I buy something, for example, from Starbucks and my friends do too, I would feel that I am part of the group" (Participant A, female). Participant R acknowledged, "It is not the same to go on stage and play with a Converse that going with your Adidas or Reebok shoes, it does not go". Sports apparel brands were often a recurring experience among brand mentions among the participants; for example, Participant $\mathrm{K}$ (male) related, "As soon as you get to the court, the boys take out their rackets and put on the halftime to see the brand the racket, what model it is (...) the same thing happens in soccer".

This was also the case with the brands mentioned in P2b (Establishment of belonging conduits) in which it was noted that the target group's influences can act as a conduit. Participant C (female) illustrated this when she argued that she used the brands "Adidas, Nike, so (...) buying some makes me feel a little more belonging, because my environment is full of people who play sports". Participant V (male) stated, "The majority belong to the design, advertising and creativity group, we all use Apple". In this way, brands seem to become fit vessels to leverage the assembly of belonging relationships between people. The answers in the follow-up questionnaire were consistent with this view: "The interest of the whole group is necessary, but once it has been adapted within it (Participant L, female)" and "When someone [from the group] starts with the product or brand they prefer" (Participant I, female).

Similarly, the participants stated that the target group directly and indirectly influences which products or services may serve as conduits to belonging (P2b). A participant 
stated that he wanted to be part of a group so he ate similar foods to those of the group members: "Those who work in the office usually opt for healthy food, then [to] integrate with them it is also why I have healthy meals and we agree on the matter of eating healthy"(Participant $\mathrm{N}$, male). Another participant also shared his experience of the group's influence when she related, "My friends want to go to Starbucks and I have to go because I know they will take that picture with the cup" (Participant L, female).

Finally, P2c also matched the predicted theoretical pattern because the participants revealed that the products and/or services used as conduits for belonging do so because of their functional or symbolic nature.

Belonging cues: In relation to the cues of signs (P3), the participants certified that they could establish and identify those cues that show their belonging status concerning a specific group. One participant thus shared this: "I usually use Adidas almost always and, somehow, it is like you wear Adidas shoes and they say 'Hey, you bought that pair', 'Yes. You know what? I saw them there, in a sale. Do you remember when we went to see them?'; so, it's like many times the conversation revolves around this product" (Participant $\mathrm{N}$, male). Participant X (female) related that she noticed when a specific product or consumption practice is leveraging its belonging when "[there is] a follow-up of posts [on Instagram], not only at once, but that it has a sequence, (...) That they ask me for recommendations maybe from places I attend to eat that kind of food".

Based on the descriptive coding analysis performed, a phenomenon which was not specified within the BP propositions used in the pattern matching, emerged among the participants. The phenomenon may be referred to as 'Some group members belong more than others'. The participants expressed the view that it was possible for someone to have a more engrained or better-established belonging status within a group based on their consumption intensity of a product or brand. One participant thus explained this: "In the gym group (...) there are some that enjoy buying powder supplements; this supplements (...) not that it keeps you united [to the group] because you can still be part of it bringing nothing (...) but you could say those who buy it are like they have a plus (...) Like they take it more seriously, they spend their money on supplements, a diet, that things" (Participant $\mathrm{R}$, male). The ownership of that belonging, which Participant $\mathrm{R}$ referred to as plus, suggests the degree of involvement of an individual with the group as his consumption denotes relevant factors about the group's identity or characteristics. A female participant noted, "There are distinguishable groups, I have noticed that, they are entirely Apple-I mean Mac, iPhone, stuff like that". She added that the identification of that group seems to be precisely delineated-"distinguishable groups"-by the specific consumption of branded products. This category emerged from the descriptive coding of information shared by the participants when they spoke about consumption practices and belonging to third parties. The category does not refer to the self-experience about consumption linked to their own belonging status, but to the belonging perceived from the perspective of a third party, based on the subject's consumption behaviour. Participant A argued that groups are discernible because of the products they use, pointing to a belonging status from an outside viewer perspective.

\section{Discussion}

Hammersley (2002) argued that a theory must be applicable to all circumstances where the specified conditions are met. This appeared to occur with the initial BP theory 
proposed by Arias and Otnes $(2016,2017)$ as it was tested in a case in which the presence of its relevant theoretical conditions was empirically observed. The results of this study suggest that it is possible to affirm that BP is transferable because it can describe and explain the stages followed during consumption behaviours oriented to promote the group belonging of individuals of a different cultural and social context to that of the original study. The participants of this study found instruments in the consumer market that allowed them to build and manifest their status of belonging, a phenomenon explained by the constructs proposed by Arias and Otnes.

Arias and Otnes $(2016,2017)$ noted that their participants mentioned popular branded products and luxury brands as frequent belonging conduits. Furthermore, the clothing and technology categories represented most of the conduits mentioned by the participants. Similarly, the participants of this study mentioned specific popular brands, particularly, technology products and clothing predominantly as conduits (see Figure 1). As some brands position their products on features aligned with the lifestyle of their consumers (Chernev, Hamilton, \& Gal, 2011), using brands as a means to favour belonging is related to preceding research where some have argued that individuals use the symbolic nature of consumption to communicate information about themselves to others (Hammerl et al., 2016; Mead et al., 2011; Ratner et al., 1999). In particular, branded products and consumer practices are used to project an individual's identity to others within their social environment (Berger \& Heath, 2007; Belk, 1988; Holt, 1997).

Although people recognise the groups to which they belong, or wish to belong, these goals do not appear to be the result of a systematic effort to identify and measure their progress, but rather to be roughly defined. The participants' statements suggest that people achieve an experienced sense of belonging due to their proactive use of consumption and goods as a means. Furthermore, this experience relates to their belonging status concerning the desired group known as belonging target. Arias and Otnes $(2016,2017)$ noted that sense of belonging has a wide range of manifestations including maintaining simple interactions with peers and establishing stable relationships with fellow members of the group. It seems that participants follow paths that require little calculation or excessive elaboration. The findings show this in relationship with the symbolic or functional quality of a product when it is to be used as an affiliation instrument. Subjects do not seem to stop and reflect on it, but simply choose it. The same seems to be the case regarding the belonging obstacles, as the interviewees recognise those that directly affect their goal, but do not spend much time thinking about identifying other ways in which obstacles can occur between the desire to belong and instrumentalised consumption.

The research findings also revealed that culture, as described in the BP framework, remains an overarching influence on the phenomenon. This is shown in the ways belonging is experienced and the selection of market available means and actions to achieve it. When the participants shared their experience, they referred to personal environments and circumstances, for example, groups of people who occasionally play music in bars, entrepreneurship groups and those who study for a career at a specific university. They shared their thoughts and behavioural traits in relation to their values and cultural norms. The same may be noted about the market in which events of belonging-oriented consumption occur because the consumption of products and their use as conduits can only follow within the framework of the goods that are accessible in 
each consumer's market. It is noteworthy that the belonging conduits are defined as resources available in the market, which indicates that the market context is as relevant and overarching to the use of goods to promote belonging as the cultural context in which this develops. Participant L (female) related, "The members of the group should be aware of the news about the product or brand, and so they can have something interesting in common to talk about". News about a brand is only available within the market in which the group members belong and to which they have access. Incorporating the market context as an element is a new contribution to the model analysed.

The findings present another new aspect that can complement the BP framework and its constructs in relation to their descriptive capacity and deepening of the relationships between them. The emergent category 'Some group members belong more than others' indicated that some group members may have a higher belonging status among their peers as a result of their volume or frequency of the consumption of a product. For example, among sports fans, individuals who consume more nutritional supplements show greater commitment to the sport activity. This may be perceived as a major involvement amongst fellow group members or at least holders of a belonging status of greater notoriety. This phenomenon may be classified as gradualness in belonging perceived by a third party; a gradualness that is related to the levels of consumption exhibited by the individual. Using marketing jargon, the individual may be classified as a light or a heavy user of a product, which may correspond with their perceived belonging status. However, Arias and Otnes' $(2016,2017)$ original definition does not reveal the possibility of gradualness once group belonging is reached. Furthermore, the degree of perceived belonging by an external observer can serve as a belonging cue because it is information that allows someone to track their progress toward a belonging target. Despite this relation, it occurs differently to that described in BP. Arias and Otnes' definition implies that belonging cues only have one direction: from an external or internal source toward the self-awareness of the individual who seeks to belong to a group. However, according to the findings, an external observer's perception proceeds in the opposite direction: from the person A whose consumption gives rise to information about its affiliation to person B who receives it and decodes, giving rise to B's perception about A's degree of group belonging. This finding could be incorporated into the characteristics of the construct of belonging cues as a precision and source of added information to the external cues included in its description. These findings are consistent with those of Heatherton (2011) who stated that if human beings fundamentally need to belong, then they must also have a mechanism aimed at detecting the state of inclusion. Such a mechanism would even allow an individual to distinguish the belonging status of a third party, even if this individual is not a group member. Also on this subject, confirmation of the belonging cues by third parties does not seem to be decisive, as participants perceive that they can self-confirm those cues when they already consider that a product, brand, or a consumption activity indicates their affiliation.

Arias and Otnes $(2016,2017)$ determined that the belonging conduits are the resources available in the market that a consumer may employ as vehicles to promote their belonging status. They specified that conduits may be products, services, brands and experiences. They added that they are used because of their functional or symbolic properties. However, a participant of this study mentioned a new factor that could add precision to the construct: to include the geo-location of the product that is chosen 
as a belonging conduit when is shared in a publication on social networks, given that geo-location is not a product or brand. Consequently, it may be feasible to consider the conduit's exhibition media as a conduit as well, namely, a resource available in the market when used to favour consumption oriented to belonging.

Besides analysing consumer behaviour aimed at belonging, Arias and Otnes' (2016, 2017) theoretical framework had a second purpose: to argue that belonging is a procedural reality. However, it appears that it is possible to use the BP framework exclusively as an explanation for consumption behaviour oriented to belonging and not argue about the continuous or static reality of the belonging phenomenon. We offer a visual model of the consumption process oriented to belonging only by framing each construct related to this behaviour (Figure 2). This model differs from BP as it comprises three new elements: the overarching market factors; the notion that the process is circular as the final goal to experience the sense of belonging happens when the individual attains membership status to the belonging target, which is also the construct by which the process starts; and that belonging obstacles may affect belonging conduits when they do not trigger positive belonging cues, that is, when individuals choose a product that is not to the pleasing or customs of the group to which they wish to belong and belonging cues when they do not signal the belonging status relative to the belonging target, namely, when consumers do not have the capability to interpret or do not pay adequate attention to the signs that show their belonging status if they have progressed toward being a member of the group or if they still hold their affiliation with the group. We also suggest a revision of the theoretical framework's name because 'belonging process' makes more reference to the experiential nature of belonging rather than the action and steps of consuming to promote group affiliation. 'Belonging directed consumption process' may be an alternative but more descriptive title. These propositions are depicted in Figure 2.

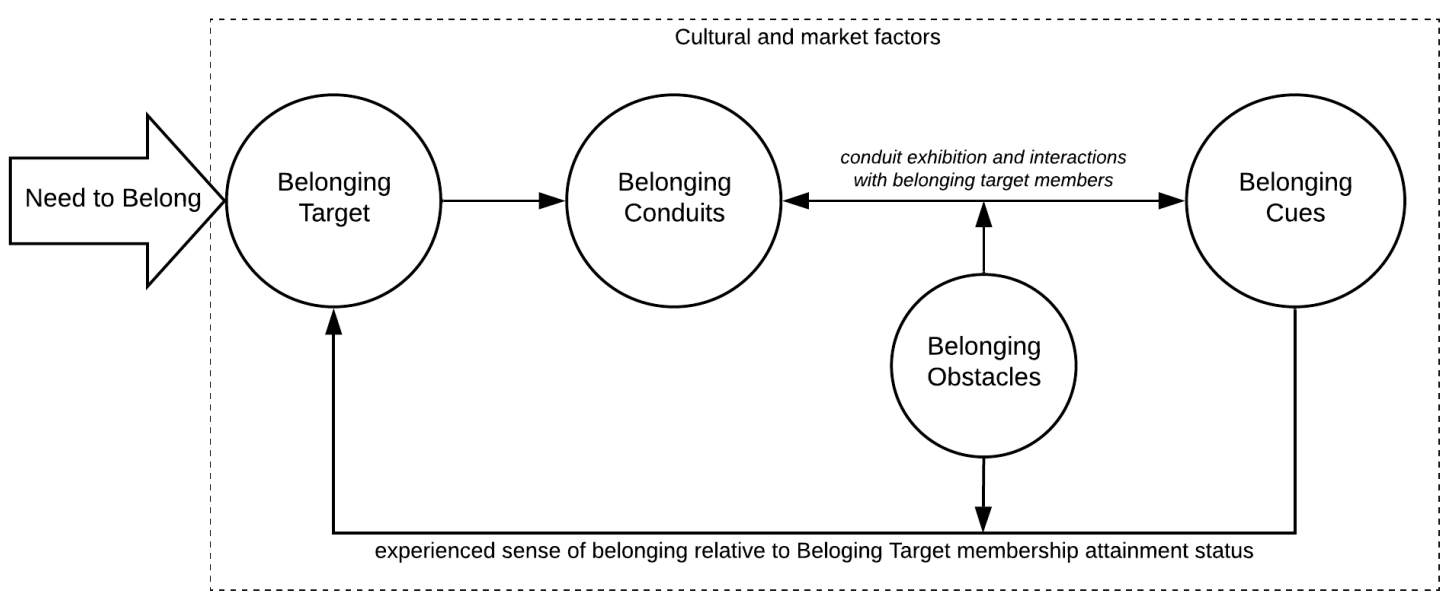

Figure 2. Version of the theoretical framework with the suggested elements, characteristics and alternative name, "Belonging directed consumption".

This study has similar limitations to those reported by Arias and Otnes $(2016,2017)$ including not incorporating the unfolding of each construct but keeping the analysis at a general level. It is recommended that the constructs be examined individually and in more depth in a future study, in order to comprehend their characteristics and how they 
function with respect to consumer behaviour, the choice of products or brands, and relationships between people. Furthermore, the possibility of analysing whether this theoretical framework describes the purchase to belonging behaviour in diverse age groups remains open. Thus, it is recommended that the model be expanded to include such. It is also recommended that a future study analyse whether the expected belonging experience happens in a unique manner or if it accepts diverse degrees of group affiliation. This work was limited to analysing the BP model in situations where the intention to consume in order to promote group affiliation is conscious and direct. However, much of our consumption happens in a nuanced and unreflective way, and the same must go for consumption related to belonging. It will be appropriate to continue researching this issue when the consumption decision is one of low involvement or when the purchase decision is preceded by little reflection. Future research may examine the process followed when belonging oriented consumption occurs in a preattentive state.

\section{References}

Algesheimer, R., Dholakia, U. M., \& Herrmann, A. (2005). The Social Influence of Brand Community: Evidence from European Car Clubs. Journal of Marketing, 69(3), 19-34. https://doi.org/10.1509/jmkg.69.3.19.66363

Almutairi, A. F., Gardner, G. E., \& McCarthy, A. (2014). Practical guidance for the use of a pattern-matching technique in case-study research: A case presentation. Nursing \& Health Sciences, 16(2), 239-244. https://doi.org/10.1111/nhs.12096

Arias, R. (2016). Toward a Conceptual Understanding of Belonging in Consumer Research. In Advances in Consumer research (Vol. 33, pp. 212-217). https://doi.org/10.1086/429607

Arias, R., \& Otnes, C. (2016). Illuminating consumers' proactive pursuits of the sense of belonging. In Jacobs Michelle (Ed.), Robert Mittelstaedt doctoral symposium proceedings. University of Nebraska-Lincoln. (pp. 23-38).

Arias, R., \& Otnes, C. (2017). The Belonging Process: Elements and Enactment Within a Consumption Context. In A. Gneezy, V. Griskevicius, \& P. Williams (Eds.), NA Advances in Consumer Research (Vol. 45, pp. 500-502). Duluth, MN: Association for Consumer Research. https://doi.org/43008804

Arvidsson, A., \& Caliandro, A. (2016). Brand Public. Journal of Consumer Research, 42(5), 727-748. https://doi.org/10.1093/jcr/ucv053

Baumeister, R. F., \& Leary, M. R. (1995). The Need to Belong: Desire for Interpersonal Attachments as a Fundamental Human Motivation. Psychological Bulletin. https://doi.org/10.1037/0033-2909.117.3.497

Bearden, W. O., \& Etzel, M. J. (1982). Reference Group Influence on Product and Brand Purchase Decisions. Journal of Consumer Research, 9(2), 183. https://doi.org/10.1086/208911

Belk, R. (2017). The Self in Consumption. In M. J. Jansson-Boyd, C. \& Zawisza (Ed.), Routledge International Handbook of Consumer Psychology (pp. 167-184). Routledge.

Belk, R. W. (1988). Possessions and the extended self. Journal of consumer research, 15(2), 139-168.

Beran, T. N., Kaba, A., Caird, J., \& McLaughlin, K. (2014). The good and bad of group conformity: A call for a new programme of research in medical education. Medical 
Education, 48(9), 851-859. https://doi.org/10.1111/medu.12510

Berger, J., \& Heath, C. (2007). Where Consumers Diverge from Others: Identity Signaling and Product Domains. Journal of Consumer Research, 34(2), 121-134.

https://doi.org/10.3174/ajnr.A5382

Bettman, J. R., \& Escalas, J. E. (2005). Reference Groups, and Brand Meaning. Journal of Consumer Research, 32(3), 1-10.

Bitektine, A. (2008). Prospective Case Study Design Qualitative Method for Deductive Theory Testing. https://doi.org/10.1177/1094428106292900

Burnkrant, R. E., \& Cousineau, A. (1975). Informational and Normative Social Influence in Buyer Behavior. Journal of Consumer Research, 2(3), 206. https://doi.org/10.1086/208633

Campbell, D. T. (1975). "Degrees of Freedom" and the Case Study. Comparative Political Studies, 8(2), 178-193. https://doi.org/10.1177/001041407500800204

Chernev, A., Hamilton, R., \& Gal, D. (2011). Competing for Consumer Identity: Limits to Self-Expression and the Perils of Lifestyle Branding. Journal of Marketing, 75(3), 66-82. https://doi.org/10.1509/jmkg.75.3.66

Childers, T. L., \& Rao, A. R. (1992). The Influence of Familial and Peer-Based Reference Groups on Consumer Decisions. Journal of Consumer Research, 19(2), 198. https://doi.org/10.1086/209296

Cialdini, R. B., \& Goldstein, N. J. (2004). Social influence: Compliance and conformity. Annual Review of Psychology (Vol. 55).

https://doi.org/10.1146/annurev.psych.55.090902.142015

Creswell. (2014). Research Design: Qualitative, Quantitative, and Mixed Methods Approaches / SAGE Companion. Sage Publications.

Creswell, J. W. (2007). Qualitative inquiry \& research design: choosing among five approaches (3rd ed.). Sage.

Fereday, J., \& Muir-Cochrane, E. (2006). Demonstrating rigor using thematic analysis: A hybrid approach of inductive and deductive coding and theme development. International journal of qualitative methods, 5(1), 80-92.

Goulding, C., Shankar, A., \& Canniford, R. (2013). Learning to be tribal: Facilitating the formation of consumer tribes. European Journal of Marketing, 47(5), 813-832. https://doi.org/10.1108/03090561311306886

Griskevicius, Vladas, \& Kenrick, D. T. (2013). Fundamental motives: How evolutionary needs influence consumer behavior. Journal of Consumer Psychology, 23(3), 372386. https://doi.org/10.1016/J.JCPS.2013.03.003

Grotts, A. S., \& Johnson, T. W. (2013). Millennial consumers' status consumption of hand bags. Journal of Fashion Marketing and Management, 17(3), 280-293. https://doi.org/10.1108/JFMM-10-2011-0067

Grzeskowiak, S., \& Sirgy, M. J. (2007). Consumer Well-Being (CWB): The Effects of SelfImage Congruence, Brand-Community Belongingness, Brand Loyalty, and Consumption Recency. Applied Research in Quality of Life, 2(4), 289-304. https://doi.org/10.1007/s11482-008-9043-9

Hak, T., \& Dul, J. (2010). Pattern Matching. In A. J. Mills, G. Durepos, \& E. Wiebe (Eds.), Encyclopedia of Case Study Research (pp. 664-665). Sage Publications.

Hammerl, M., Dorner, F., Foscht, T., Brandstätter, M., \& Brandstätter, M. (2016). Attribution of symbolic brand meaning: the interplay of consumers, brands and reference groups. Journal of Consumer Marketing, 33(1).

https://doi.org/10.1108/JCM-12-2014-1243

Hammersley, M. (2002). The relationship between qualitative and quantitative 
research: paradigm loyalty versus methodological eclecticism. In J. T. Richardson (Ed.), Handbook of Qualitative Research Methods for Psychology and the Social Sciences (pp. 159-174). Oxford: BPS Blackwell.

Holt, D. B. (1997). Poststructuralist Lifestyle Analysis: Conceptualizing the Social Patterning of Consumption in Postmodernity. Journal of Consumer Research, 23(4), 326. https://doi.org/10.1086/209487

Hornsey, M. J., \& Jetten, J. (2004). The Individual Within the Group: Balancing the Need to Belong With theNeedtoBeDifferent. Personality and Social Psychology Review, 8(3), 248-264. https://doi.org/10.1207/s15327957pspr0803

Hyde, K. F. (2000). Recognising deductive processes in qualitative research. Qualitative Market Research: An International Journal, 3(2), 82-90. https://doi.org/10.1108/13522750010322089

Løkke, A., \& Sørensen, P. D. (2014). Theory Testing Using Case Studies Interdisciplinary Centre for Organizational Architecture (ICOA), School of Business and Social, 12(1), 66-74.

McCracken, G. (1986). Culture and Consumption: A Theoretical Account of the Structure and Movement of the Cultural Meaning of Consumer Goods. Journal of Consumer Research, 13(1), 71. https://doi.org/10.1086/209048

Mead, N. L., Baumeister, R. F., Stillman, T. F., Rawn, C. D., \& Vohs, K. D. (2011). Social Exclusion Causes People to Spend and Consume Strategically in the Service of Affiliation. Journal of Consumer Research, 37(5), 902-919.

Mellor, D., Stokes, M., Firth, L., Hayashi, Y., \& Cummins, R. (2008). Need for belonging, relationship satisfaction, loneliness, and life satisfaction. https://doi.org/10.1016/j.paid.2008.03.020

Miller, W. L., \& Crabtree, B. F. (2005). Clinical Research. In N. K. Denzin (Ed.), The Sage handbook of qualitative research (3rd ed., pp. 605-639). Thousand Oaks: Sage Publications.

Muniz, A. M., \& O'Guinn, T. C. (2001). Brand Community. Journal of Consumer Research, 27(4), 412-432. https://doi.org/10.1086/319618

Nadkarni, A., \& Hofmann, S. G. (2012). Why Do People Use Facebook? Personality and Individual Differences, 52(3), 243-249. https://doi.org/10.1016/j.paid.2011.11.007

Nichols, A. L., \& Webster, G. D. (2013). The single-item need to belong scale. Personality and Individual Differences, 55(2), 189-192. https://doi.org/10.1016/J.PAID.2013.02.018

Oishi, S., Diener, E., Suh, E., \& Lucas, R. E. (1999). Value as a moderator in subjective well-being. Journal of Personality, 67(1), 157-184. https://doi.org/10.1111/14676494.00051

Pearse, N. (2019). An Illustration of Deductive Analysis in Qualitative Research. In A. Stacey (Ed.), ECRM 2019 18th European Conference on Research Methods in Business and. (pp. 264-268). Johannesburg: Academic Conferences and Publishing International Limited. https://doi.org/10.34190/RM.19.006

Pickett, C. L., Gardner, W. L., \& Knowles, M. (2004). Getting a Cue: The Need to Belong and Enhanced Sensitivity to Social Cues. Personality and Social Psychology Bulletin, 30(9), 1095-1107. https://doi.org/10.1177/0146167203262085

Ratner, R. K. K., Kahn, B. E. E., \& Kahneman, D. (1999). Choosing Less-Preferred Experiences For the Sake of Variety. Journal of Consumer Research, 26(1), 1-15. https://doi.org/10.1086/209547

Ruane, L., \& Wallace, E. (2015). Brand tribalism and self-expressive brands: Social influences and brand outcomes. Journal of Product and Brand Management, 24(4), 
333-348. https://doi.org/10.1108/JPBM-07-2014-0656

Saldana, J. (2013). The coding manual for qualitative researchers. London: Sage.

Schulz, H. M. (2015). Reference group influence in consumer role rehearsal narratives. Qualitative Market Research: An International Journal, 18(2), 210-229. https://doi.org/10.1108/QMR-02-2012-0009

Seidman, G. (2013). Self-presentation and belonging on Facebook: How personality influences social media use and motivations. https://doi.org/10.1016/j.paid.2012.10.009

Sinkovics, N. (2017). Pattern matching in qualitative analysis. In C. Casell, A. Cunliffe, \& G. Grandy (Eds.), The Sage Handbook of Qualitative Business and Management Research Methods (p. 1056). Thousand Oaks: Sage Publications.

Stuckey, H. L. (2015). The second step in data analysis: Coding qualitative research data. Journal of Social Health and Diabetes, 3(1), 7-10. https://doi.org/10.4103/23210656.140875

Trochim, W. M. K. (1985). Pattern Matching, Validity, and Conceptualization in Program Evaluation. Evaluation Review, 9(5), 575-604. https://doi.org/10.1177/0193841X8500900503

Veloutsou, C., \& Moutinho, L. (2009). Brand relationships through brand reputation and brand tribalism. Journal of Business Research, 62(3), 314-322. https://doi.org/10.1016/j.jbusres.2008.05.010

White, K., \& Argo, J. J. (2009). Social identity threat and consumer preferences. Journal of Consumer Psychology, 19(3), 313-325.

Yin, R. K. (1981). The Case Study Crisis: Some Answers. Administrative Science Quarterly, 26(1), 58. https://doi.org/10.2307/2392599

Yin, R. K. (2006). Case Study Methods. In J. L. Green, G. Camilli, \& P. B. Elmore (Eds.), Handbook of complementary methods in education research (pp. 111-122).

Mahwah, NJ, US: Lawrence Erlbaum Associates Publishers.

Yin, R. K. (2018). Case Study Research Design and Methods (6th ed.). Los Angeles: Sage. 